\title{
Why you should talk to yourself: internal dialogue and reflective practice
}

\section{John Launer}

When children talk to themselves out loud, their classmates commonly tease them by saying this is the first sign of madness. It is a cruel taunt but also an inaccurate one. Talking to yourself is normal at all age ${ }^{1}$ and so is talking to trees and other inanimate objects. To emphasise this point, a psychiatrist even appeared on television in Germany earlier this year to ask people not to overwhelm his profession with concerns about talking to flowers and walls when under quarantine, and he advised them only to call if the flowers or walls started to talk back. ${ }^{2}$ Talking to yourself can in fact be beneficial in certain circumstances, such as enhancing performance in sport, $^{3}$ finding objects that have been mislaid $^{4}$ and developing problem-solving skills. ${ }^{5}$ Personally, I have never believed that it is mad to talk to yourself, but I have often said to medical colleagues and trainees, half in jest, that the opposite is certainly true: the first sign of madness is when you stop talking to yourself. In this case, I am not necessarily referring to speaking your thoughts aloud-although that can sometimes be helpful too. I am trying to encourage what is called inner speech or internal dialogue, as part of reflective practice.

Reflection in the literal sense means looking at yourself in a mirror. Much discussion of reflective practice uses language related to vision, like 'self-observation', rather than referring to the capacity to speak and listen to yourself. In reality, however, most of us probably listen to our inner voices far more than we ever look at ourselves in mirrors. Talking about the importance of internal dialogue might therefore be a better way of promoting reflective practice than using visual language. Although some people report thinking mainly in pictorial images, ${ }^{6}$ most medical communication with patients and colleagues is predominantly verbal, so it seems likely that most doctors use inner speech at work more than visual imagination. It also makes sense to assume that attunement to internal dialogue, including how we each think in advance about what to say, can help to improve the quality of such communication.

Correspondence to Dr John Launer, Associate Editor, Postgraduate Medical Journal, London WC1H 9JP, UK; johnlauner@aol.com

\section{INNER DEBATES}

I happen to be someone with what you might call a very loud internal dialogue, so I often engage in inner debates or even arguments with myself, and occasionally vocalise them when alone. While this is sometimes intrusive-for example, when I would prefer to be inwardly silent and just enjoy the scenery during a walk-it also means I am able to describe for others in some detail what my reflections are like when engaged in professional work. Here, for instance, is a brief account of what is likely to be going through my head when running a case-based discussion with a group of trainees (something I do a lot). It may help to inform people who find it harder to track their own inner voices, or who would like to compare theirs with someone else's.

From the beginning of the discussion, I am intentionally debating with myself when I should make an intervention-a question or a comment-and exactly what I should say. I may consider in my own mind whether I should speak early on, to steer the conversation away from an unimportant theme brought in by someone quite dominant, or allow it to flow in order to allow a fruitful exchange of ideas where everyone is taking part. I also wonder how to phrase my contribution to promote more dialogue rather than shutting it down, and what effect my words will have on the dynamics of the group. After speaking, I try to remain alert to what happens as a result, and my inner dialogue turns to the process of recalibration: did my intervention have the effect I hoped, and what should I learn from that about my timing and way of expressing myself next time? I would say that this iterative process of rehearsal, review and recalibration has always been present in my head during professional encounters, in everything from conversations with patients to committee meetings. I also hope I have learnt to become more attentive and responsive to it over the years, and I believe that many other doctors and educators do so as well. The illustration here related only to group discussions and not to situations requiring practical actions, but it should not be hard to imagine how the same inner dialogue, alongside a conversation with others present, might inform a physician when deciding which treatment to prescribe, or a surgeon when contemplating the next move in an operation. ${ }^{7}$

\section{TUNING IN TO YOUR INNER VOICES}

Some professions train students to tune in to their own inner voice or voices, so that these become more accessible as part of their everyday practice and decision-making. A group of mental health professionals in New South Wales, for example, has devised an exercise that involves presenting a case vignette to trainees, asking them to identify and articulate the 'polyphony' of different responses these evoke in their own thoughts, and to share these with each other. ${ }^{8}$ The authors write: 'Attunement to this range of inner voices, feelings, and urges (including contradictory ones) can open the door for greater flexibility and a broader repertoire of possible responses'. Similarly, all psychoanalysts are taught how to bring their own thoughts and feelings into consciousness and to scrutinise these for hints they may give about what is occurring in the thoughts and feelings of the patient beside them. Such training is far less common in medicine, although the increasing use of reflective writing in medical schools and postgraduate training, as well as in appraisals, may cultivate such awareness even though the writing is done afterwards. Such retrospective analysis is sometimes called 'reflection on action' in contrast to the 'reflection in action' that takes place during live encounters, ${ }^{9}$ but it may help to encourage reflection at the moment as well. ${ }^{10}$

One teaching technique is particularly effective in helping people to tune in to their internal voices and works in medicine too. It involves pausing or 'freezing' the conversation and asking students or trainees questions like 'what was going through your mind when you made that suggestion?', 'what was your reasoning at that point' or 'did you entertain any other ideas before you came up with that one?'. In a group discussion, it is also possible to ask everyone to give voice to their own internal dialogue at the moment the conversation was paused, and for this to become part of the spoken debate. A refinement of this approach is to nominate one or two people as observers, and then to ask them to comment from time to time on what they have heard, both from the participants within the group and from their own inner reflections. ${ }^{11}$

I would like to predict that one of the next big developments in medical education, particularly at the postgraduate level, will be to make the importance of inner dialogue more explicit, to promote awareness of it through exercises and techniques of this kind, and to research what difference it makes to medical performance. Perhaps, we will even replace the idea of 'reflective practice' in time with one simple principle: 'Keep talking to yourself'. 


\section{On reflection}

Twitter John Launer @JohnLauner.

Funding The authors have not declared a specific grant for this research from any funding agency in the public, commercial or not-for-profit sectors.

Competing interests None declared.

Patient consent for publication Not required.

Provenance and peer review Not commissioned; internally peer reviewed.

(C) Author(s) (or their employer(s)) 2020. No commercial re-use. See rights and permissions. Published by BMJ.

\section{A Check for updates}

To cite Launer J. Postgrad Med J 2020;96:507-508.

Postgrad Med J 2020;96:507-508.

doi:10.1136/postgradmedj-2020-138455

\section{REFERENCES}

1 Gould WR Go ahead, talk to yourself. It's normal: and good for you. Available https://www.nbcnews.com/ better/health/talking-yourself-normal-here-s-howmaster-it-ncna918091 (accessed 26 May 2020)

2 Available https://twitter.com/i/status/ 1261202666484576258 (accessed 26 May 2020)

3 Van Raalte JL, Vincent A. Self-talk in sport and performance. In: Oxford Research Encyclopaedia, Psychology. 2017. Available https://oxfordre.com/psychology/view/ 10.1093/acrefore/9780190236557.001.0001/acre fore-9780190236557-e-157 (accessed 26 May 2020).

4 Lupyan G, Swingley D. Self-directed speech affects visual search performance. Q J Exp Psychol 2012;65:1068-85

5 Berry DC. Metacognitive cognition and transfer of logical reasoning. Q J Exp Psychol Sect $A$ 1983;35:39-49.

6 Hurlburt RT Not everyone conducts inner speech. Psychol Today 26 October 2011. Available https:// www.psychologytoday.com/us/blog/pristine-innerexperience/201110/not-everyone-conducts-innerspeech (accessed 26 May 2020)

7 Countercurrent: conversations with professor Roger Kneebone, 11 December 2017. Available https:// rogerkneebone.libsyn.com/dr-john-launer-inconversation-with-roger-kneebone-0 (accessed 26 May 2020)

8 Mikes-Liu K, Goldfinch M, MacDonald C, et al. Reflective practice: an exercise in exploring inner dialogue and vertical polyphony. Austral NZ J Fam Ther 2016:37:256-72.

9 Schon D. The reflective practitioner: how professionals think in action. New York: Basic Books, 1984.

10 Hughes G. Talking to oneself: using autobiographical internal dialogue to critique everyday and professional practice. Reflective Pract 2009;10:451-63.

11 Launer J. Supervision quartets. Postgrad Med J 2012:88:185-6. 